Олег Мітягін

кандидат історичних наук

ORCID ID 0000-0003-1941-3561

Анатолій Чайковський

доктор історичних наук, професор,

Національний університет оборони України

імені Івана Черняховського

\title{
ІНФОРМАТИЗАЦІЯ ВІЙСЬКОВОЇ ОСВІТИ - ПОТРЕБА СУСПІЛЬСТВА В ПІДГОТОВЦІ ВІЙСЬКОВИХ ФАХІВЦІВ ДЛЯ ЗБРОЙНИХ СИЛ УКРАЇНИ
}

У статті розглядається актуальність дослідження проблеми підвищення ефективності військово-педагогічного процесу та якості підготовки військових фахівців на основі інформатизаиї військової освіти й подальшого впровадження інформачійних технологій. Визначено основні завдання та иляхи, щуо має вирімувати інформатизація освіти, перераховано основні загальні тендениії й напрями впровадження інформаційних технологій в систему військової освіти. Розглянуто актуальність інформаційної підготовки в системі підготовки військових фахівців.

Ключові слова: система військової освіти; інформачійні технологї навчання; комп'ютерні мережі навчальних закладів; комп'ютерна технологія навчання; дистанційне навчання; інформаційна підготовка військових фахівців.

Постановка проблеми. Світ швидко змінюється. В усіх сферах людської діяльності зростає роль інформаційних процесів, підвищується потреба в інформації та засобах для іï створення, обробки, зберігання i використання. Сучасна модернізація освіти стимулюється соціальним замовленням суспільства, а тому ставить нові вимоги до рівня підготовки випускників вищих навчальних закладів, зокрема військових. Посилюється інформатизація освіти, відбувається включення до системи освіти інформаційного середовища й залучення інтернет-ресурсів. Але поки ще не створено систему єдиного освітнього простору у вищих військових навчальних закладах на основі розвитку інформаційно-освітньої мережі для підготовки фахівців Збройних Сил України.

Аналіз останніх досліджень та публікацій. Дослідженням щодо безпосереднього використання комп'ютерної техніки, програмних та методичних розробок у навчально-виховному процесі присвятили свої праці О. Довгялло, К. Жоль, Г. Козлакова, Ю. Машбиць, В. Михалевич, Ю. Сиволоб, А. Стогній.

Проблему підготовки військових фахівців за допомогою засобів інформаційних технологій розглянуто у працях О. Блажука, О. Діденка, Л. Романишиної, І. Романюка, Д. Таушана, В. Ягупова, А. Янковця тощо.

Методи дослідження: аналіз, синтез, моделювання, традиційнопедагогічні методи, узагальнення. 
Метою статті $\epsilon$ визначення основних завдань та шляхів, що має вирішувати інформатизація освіти, основних загальних тенденцій і напрямів упровадження інформаційних технологій у систему військової освіти.

Виклад основного матеріалу. Проникнення в освіту нових інформаційних технологій змушує подивитися на дидактичний процес як на процес інформаційний. Поняття «інформатизація» вживається разом 3 поняттям «комп’ютеризація», що означає процес розвитку та впровадження комп'ютерів, які забезпечують автоматизацію інформаційних процесів i технологій у різних сферах людської діяльності [3].

Інформатизація - це сукупність взаємопов'язаних організаційних, правових, політичних, соціально-економічних, виробничих процесів, що мають на меті створити умови для задоволення інформаційних потреб громадян i суспільства завдяки розробці, розвитку й використання інформаційних систем, мереж ресурсів та технологій, які базуються на застосуванні сучасної обчислювальної та комунікаційної техніки (стаття 1 Закону України «Про Національну програму інформатизації» від 04 лютого 1998 року № 74 (із наступними змінами)) [7].

Інформатизація освіти - це частина інформатизації суспільства, процесу, який від середини XX сторіччя набрав характеру інформаційного вибуху, що дає підстави характеризувати сучасне суспільство як інформаційне. Зростання потреби в інформації та збільшення іï потоків в людській діяльності зумовлюють появу нових інформаційних освітніх технологій, теоретичною основою розробки яких $\epsilon$ інформатика, кібернетика, теорія систем i дидактика.

У дослідженнях науковця Ю. Триуса інформатизація освіти розглядається як сукупність взаємопов'язаних процесів (організаційних, управлінських, науково-технічних, навчальних, виховних), спрямованих на створення умов для задоволення інформаційних потреб усіх учасників освітнього процесу, розвитку їх інтелектуального потенціалу, самореалізації і самовдосконалення, забезпечення підготовки до повноцінної професійної діяльності та життя в інформаційному суспільстві на основі створення, розвитку й використання сучасних інформаційно-комунікаційних систем, мереж, ресурсів і технологій [6].

Зазначимо, що інформатизація освіти - це планомірний, послідовний i систематизований процес підготовки фахівців до праці в умовах сучасного інформатизованого суспільства, підвищення якості їх загальноосвітньої та фахової підготовки на основі широкого використання комп'ютерної та іншої інформаційної техніки, мережі Інтернет.

Інформатизація освіти вносить істотні зміни в педагогічний процес й охоплює всі ланки системи освіти, iï установи та органи управління.

Серед основних завдань, що має вирішувати інформатизація освіти, можна назвати такі:

- забезпечення розвитку особистості, розкриття ії творчого потенціалу;

- формування інформаційної культури людини; 
- удосконалення управління освітою;

- створення інформаційних мереж і баз даних;

- інтенсифікація методичної роботи й наукових досліджень;

- запровадження нових форм навчання, підготовки, перепідготовки та підвищення кваліфікації фахівців.

Вирішити ці завдання можна лише за умови розробки і впровадження нових інформаційних технологій, відповідної підготовки педагогічних кадрів, удосконалення управлінських механізмів та ресурсного забезпечення інформатизації освіти.

Важливе значення у процесі інформатизації освіти мають засоби інформаційних технологій, серед яких виділяють: інформаційнообчислювальну техніку; інформаційне забезпечення педагогічного процесу (методичні та дидактичні засоби); програмно-методичне забезпечення процесу підготовки; технологічні системи обробки інформації, що забезпечують ефективне використання технічних засобів і методів наукових інформаційних технологій [5].

Засоби інформатизації, що широко впроваджуються в освіту, впливають на $[1 ; 2 ; 4]$ : a) удосконалення процесу навчання, підвищення його ефективності; б) розвиток особистості студента; в) систему управління навчально-виховним процесом, навчальними закладами; г) поширення передових педагогічних ідей; д) реалізацію форм контролю й оцінки дій студентів; е) автоматизацію процесів обробки результатів навчального експерименту; ж) оновлення предметного змісту; з) удосконалення організації спільної діяльності.

У зв'язку з інформатизацією освітньої сфери збагачується й відповідна термінологія - з'являються такі поняття, як «комп'ютерна технологія навчання», «інформаційна технологія навчання», «інформаційнокомунікаційна технологія навчання» тощо.

Серед загальних тенденцій, що простежуються у процесі інформатизації освіти, виділимо такі:

- використання світових інформаційних освітніх ресурсів;

- виникнення нових форм підготовки й перепідготовки фахівців;

- розширення сфери використання засобів нових інформаційних технологій навчання в навчальному процесі;

- поява принципово нових засобів навчання;

- використання засобів нових інформаційних технологій навчання в позааудиторній роботі, що наближає навчальну діяльність до дослідницької, конструкторської, зменшує розрив між нею та професійною діяльністю;

- формування основ інформаційної культури у процесі вивчення навчальних дисциплін;

- переведення багатьох видів управлінської діяльності на сучасну інформаційну технологію. 
Отже, засобами й методами нових інформаційних технологій навчання мають оволодіти педагоги всіх спеціальностей, управлінці, працівники науково-методичних підрозділів та установ.

Наявна суперечність між безперервним збільшенням обсягів науковотехнічної, навчальної та соціальної інформації й обмеженими строками навчання у військових навчальних закладах, наростанням масштабів освіти i важливістю індивідуального підходу до навчання та виховання ставить на порядок денний питання про необхідність якісної зміни всього навчального процесу, пошуку нових форм і засобів оптимізації навчання. Сьогодні необхідно ставити питання щодо зміни цілей військової освіти, ії̈ принципово нової орієнтації на проблеми інформаційної цивілізації.

У сучасній динамічній обстановці виникають також проблеми, пов'язані 3 підвищенням ефективності та якості управління. Обсяг необхідних для прийняття обгрунтованих рішень відомостей, що постійно зростає, вимагає впровадження складних систем пошуку, обробки, передачі, зберігання й використання інформації в будь-якій потрібній формі - усній, письмовій або візуальній - незалежно від відстані, часу та обсягу. Для вирішення цих питань на сучасному етапі розвитку суспільства існує єдиний шлях інформатизація військової освіти.

Вона містить процес удосконалення засобів збирання, зберігання, розповсюдження, пошуку й обробки інформації, а також процес підвищення інтелектуального потенціалу всіх суб'єктів навчально-виховного процесу в системі військової освіти, тобто розвиток здібностей щодо сприйняття i створення інформації.

Система військової освіти як об'єкт інформатизації визначається такими показниками:

- багатомірністю, що зумовлена великою кількістю установ і підрозділів, які входять до складу системи й мають територіальну розкиданість;

- багатоцільовим характером функціонування, що обумовлений наявністю низки паралельних процесів діяльності, як підготовка фахівців різних освітньо-кваліфікаційних рівнів і великою кількістю напрямів підготовки, спеціальностей та спеціалізацій;

- неперервністю, цілісністю, гнучкістю, що визначені необхідністю реалізації багатоступеневого навчання військових фахівців та забезпечення їх продуктивної діяльності на всіх посадах.

Через це процес інформатизації військової освіти має низку особливостей, a саме:

- високий ступінь складності загальної системи навчання, пов'язаний 3 необхідністю оперативної зміни навчальних програм за всіма напрямами навчання;

- необхідність моделювання й аналізу складних військово-спеціальних завдань і процесів на тактичному, оперативно-тактичному та стратегічному рівнях; 
- істотне переважання інформаційних процесів над матеріальними;

- порівняно висока тривалість циклів підготовки фахівців різних освітньо-кваліфікаційних рівнів і ланок управління;

- необхідність засвоєння нових фундаментальних та прикладних знань, на основі яких створюються новітні оборонні технології.

Інформатизація військової освіти здійснюється відповідно до законодавства, що регулює відносини у сфері інформатизації, зокрема Закону України «Про Національну програму інформатизації» від 04 лютого 1998 року № 74.

Базою процесу інформатизації є новітні інформаційні технології.

Головна мета інформатизації військової освіти - підвищення якості військово-педагогічного процесу та його вартісної ефективності. Її реалізація має забезпечити:

- гарантовану якість навчання;

- індивідуалізацію, особистісну його орієнтованість як засобу розвитку творчих здібностей курсантів (слухачів);

- взаємозв'язок між практичною діяльністю, навчанням та науковими дослідженнями;

- підвищення рівня комп'ютерної грамотності педагогічних і науковопедагогічних працівників ВВНЗ, курсантів (слухачів);

- підвищення ефективності, оперативності та гнучкості управління на всіх рівнях;

- зниження вартості навчання.

На сучасному етапі розвитку ЗС України лише реальне впровадження наявних i розробка нових інформаційних та комунікаційних технологій дадуть можливість, з одного боку, забезпечити якість підготовки військових фахівців відповідно до світових стандартів, стандартів НАТО, орієнтуючись при цьому на організацію навчального процесу 3 використанням комп'ютерних технологій навчання (електронне, дистанційне навчання), а 3 іншого, - оптимізувати систему управління діяльністю військових навчальних закладів і знизити вартість навчання.

Таким чином, можна сформулювати головні завдання інформатизації військових навчальних закладів:

- підготовка військового фахівця до повноцінного життя та діяльності в умовах існування інформаційного суспільства;

- комплексна перебудова військово-педагогічного процесу, підвищення його ефективності 3 використанням новітніх інформаційних технологій навчання;

- оптимізація системи управління діяльністю військових навчальних закладів.

Серед основних напрямів інформатизації військової освіти необхідно виокремити:

- інформатизацію навчального процесу та наукової діяльності; 
- інформатизацію повсякденної діяльності військового навчального закладу й управління ним; України.

- створення інформаційної комп'ютерної мережі військової освіти

Якщо два перші напрями мають процесуальний характер, то третій $\epsilon$ технологічною основою або засобом інформатизації військової освіти. Тільки на базі єдиної інформаційної комп'ютерної мережі можливо створення, активізація та ефективне використання інформаційного ресурсу системи військової освіти, що дасть змогу досягнути цілей інформатизації військової освіти.

Усебічна комп'ютеризація навчального процесу, використання сучасних інформаційних технологій вимагають тривалого й досить складного етапу, пов'язаного зі створенням випереджувального науково-методичного забезпечення процесу підготовки військових фахівців, підготовкою, перепідготовкою науково-педагогічних кадрів, а також відповідним розвитком сучасної навчально-матеріальної бази.

Реалізація сьогоденного інформаційного забезпечення навчальновиховного процесу в системі військової освіти дасть можливість:

- оперативно отримувати різноманітну інформацію, накопичувати знання, акумулювати інтелектуальний потенціал військової освіти й науки;

- забезпечити якісну підготовку військових фахівців на усіх освітньокваліфікаційних рівнях шляхом індивідуалізації, особистісної орієнтованості навчання як одного 3 основних засобів розвитку творчих здібностей курсантів (слухачів) та самостійного здобуття ними у процесі своєї підготовки знань, умінь і навичок;

- комплексно перебудувати навчально-виховний процес у військових навчальних закладах з метою його інтенсифікації та зниження вартості;

- підвищити ефективність наукової діяльності в системі військової освіти, передусім через оперативне отримання сучасних наукових матеріалів і використання наукового інформаційного потенціалу вищої військової й цивільної школи, науково-дослідних установ та організацій.

Відсутність цілісної системи інформаційно-аналітичного забезпечення органів управління системи військової освіти та керівництва військовими навчальними закладами значно ускладнює прийняття ними виважених рішень.

Подальше підвищення якості управління системи військової освіти кожним військовим навчальним закладом вимагає автоматизації процесу збирання й обробки даних, створення інформаційних систем і баз даних із розвинутими можливостями аналітичної обробки інформації.

Ефективне вирішення вищезазначених завдань інформаційного забезпечення навчально-виховного процесу та інформаційно-аналітичного забезпечення органів управління системи військової освіти не можливе без створення комп'ютерної мережі навчальних закладів Міністерства оборони України. 
На сьогодні для забезпечення обміну інформацією між навчальними закладами, науковими й дослідними установами, а також зв'язку зі світовими комп'ютерними мережами існують приклади створення подібних комп'ютерних мереж. Так, за рішенням Міністерства освіти і науки України та Національної академії наук України створено телекомунікаційну мережу закладів освіти й науки «УРАН», що охоплює провідні університети та наукові установи Києва, Львова, Одеси, Харкова, Дніпропетровська, Донецька й інших міст України.

Через відомчі особливості та особливості підготовки військових фахівців вищі військові навчальні заклади не мають можливості бути включеними в цю систему. Тому необхідне створення власної корпоративної інформаційно-телекомунікаційної мережі системи військової освіти 3 доступом до глобальної мережі Інтернет, що б вирішила питання оперативного управління й забезпечення якісної підготовки військових фахівців усіх освітньо-кваліфікаційних рівнів із застосуванням новітніх інформаційних методів і форм навчання.

Корпоративна мережа має забезпечувати захист інформації, що передається, від несанкціонованого доступу й надавати широкий спектр мережних послуг користувачам: електрона пошта, передача файлів, робота в режимі on-line 3 інформаційними системами та базами даних. Обмін інформацією повинен забезпечуватися як між користувачами робочих станцій локальних мереж ВВН3, так і між базами даних, розташованих на серверах цих мереж.

Створення інформаційно-телекомунікаційної мережі системи військової освіти дасть змогу:

- підвищити оперативність, ефективність та якість управління системи військової освіти в цілому завдяки використанню своєчасної, точної, достовірної й повної інформації;

- створити та використовувати загальний інформаційний ресурс, накопичений у кожному ВНЗ за багато років існування;

- забезпечити взаємозв'язок між навчанням і практичною діяльністю в сучасних умовах існування ЗС.

Доступ до ресурсів глобальної інформаційної мережі Інтернет додатково дасть змогу забезпечити органи управління системи військової освіти інформаційно-аналітичними матеріалами 3 питань перспективного розвитку освітянської діяльності й міжнародного досвіду в цій галузі, використовувати навчально-методичну інформацію, накопичену в цивільних закладах освіти й науки України, підтримувати зв'язок із міжнародними організаціями, міністерствами та відомствами, що займаються освітянською діяльністю й питаннями підготовки військовослужбовців, оперативно отримувати законодавчу інформацію тощо.

Інформатизація військової освіти передбачає застосування новітніх технологій навчання на базі високоефективних комп'ютерних i телекомунікаційних технологій із широкими можливостями. 
Однією з найважливіших складових навчання у процесі інформатизації військової освіти $є$ інформаційна підготовка. Інформатизація військової освіти України вимагає вдосконалення змісту підготовки випускників військових навчальних закладів, оновлення складу навчальних дисциплін, уточнення переліку спеціальностей. Удосконалення потребує, насамперед, зміст підготовки 3 навчальних дисциплін, спрямованих на здобуття курсантами (слухачами) знань, умінь і навичок у формуванні та використанні інформаційних ресурсів загального й військового призначення, на професійну підготовку в галузі новітніх інформаційних технологій.

До освітніх програм інформаційної підготовки доцільно включити два компоненти - базовий і спеціальний.

Базовий містить фундаментальні основи в галузі інформатики і $\epsilon$ загальним для всіх спеціальностей відповідного ступеня освіти. Він формує в курсантів (слухачів) наукові знання в галузі інформаційних ресурсів та їх використання. Цей компонент орієнтований на здобуття курсантами (слухачами) комп'ютерної грамотності та інформаційної культури, зокрема володіння всіма рівнями Інтернет-сервісу (електронна пошта, передача файлів, робота з віддаленим комп'ютером, пошук даних і навігація в інтернеті, телеконференція, гіпертекстові технології, комп'ютерні аудіовідео-телеконференції в реальному масштабі часу). Зміст базового компонента мають формувати кафедри, що $\epsilon$ профілюючими в галузі інформатики (інформаційних комп'ютерних технологій) відповідних військових навчальних закладів.

Спеціальний компонент інформаційної підготовки випускників військових навчальних закладів, що має розроблятися для кожної спеціальності та спеціалізації, орієнтований на здобуття курсантами (слухачами) професійних знань, умінь і навичок у створенні й використанні інформаційних ресурсів 3 обраної спеціальності 3 урахуванням профілів службової діяльності за посадовим призначенням. Він забезпечує ефективне використання сучасних і перспективних військових інформаційних систем (штабних АСУ, АСУ родів військ, бойових АСУ), багатофункціональних інтегрованих систем управління й передачі даних між абонентами ЛОМ (військовий підрозділ, окрема оперативно-тактична одиниця, корабель) i глобальними мережами (військові з'єднання, роди військ, силові структури держави). Особливої актуальності для офіцерських кадрів набувають пошук, аналіз та ефективне використання інформаційних ресурсів загального й військового призначення, а також перспективних засобів збирання, передачі, зберігання, обробки, відображення, захисту та документування інформації, програмного забезпечення засобів зв'язку. Зміст спеціального компонента інформаційної підготовки мають формувати випускові кафедри військового навчального закладу за участю всіх кафедр, задіяних у підготовці випускників із відповідних спеціальностей і спеціалізацій. 
Інформаційна підготовка курсантів (слухачів) має включатися як обов'язковий елемент у державні освітні стандарти на військові спеціальності.

У сучасних умовах інформаційна підготовка набуває самостійної ролі поряд із тактичними, тактико-спеціальними, оперативно-тактичними, військово-технічними, військово-спеціальними дисциплінами. Це положення має стати вирішальним під час проектування навчальних планів і програм, науково-методичного забезпечення інформаційної підготовки курсантів (слухачів) військових навчальних закладів.

Висновки та перспективи подальших досліджень. Динамічний розвиток комп'ютерних та комунікаційних технологій визначив одну 3 найсуттєвіших ознак сьогодення - формування інформаційного суспільства, що характеризується глобальними процесами інформатизації всіх сфер суспільного життя, зокрема освітньої сфери, що спрямовані на ії інформатизацію, запровадження системи навчання протягом усього життя та забезпечення доступу до національних і світових інформаційних ресурсів. Одним із пріоритетних напрямів модернізації в цій галузі є впровадження інформаційно-комунікаційних технологій, що забезпечують перебудову навчально-виховного процесу у вищих військових навчальних закладах та сприяють підвищенню його ефективності, інтеграції системи вітчизняної освіти до європейського й світового освітнього простору. Ефективне вирішення завдань інформаційного забезпечення навчально-виховного процесу та інформаційно-аналітичного забезпечення органів управління системи військової освіти не можливе без створення комп'ютерної мережі навчальних закладів Міністерства оборони України. Тому необхідне створення власної корпоративної інформаційно-телекомунікаційної мережі системи військової освіти 3 доступом до глобальної мережі Інтернет, що б вирішила питання оперативного управління й забезпечення якісної підготовки військових фахівців усіх освітньо-кваліфікаційних рівнів на основі застосування новітніх інформаційних методів і форм навчання. Подальші дослідження будуть присвячені ролі та місцю дистанційного навчання як підсистеми інноваційних технологій навчання.

\section{ЛІТЕРАТУРА}

1. Адольф В. А. Профессионально-педагогические проблемы компьютерной подготовки специалистов / В. А. Адольф // Высшее образование в России. - 1997. - № 4. C. $107-109$.

2. Компьютерные технологии в высшем образовании: сб. ст. / редкол. : А. Н. Тихонов, В. А. Садовничий, В. И. Сергеев и др. - М. : МГУ, 1994. - 370 с.

3. Коваль Т. І. Теоретичні та методичні основи професійної підготовки 3 інформаційних технологій майбутніх менеджерів-економістів. Дис. ... док. пед. наук: 13.00.04 / Інститут педагогічної освіти і освіти дорослих АПН України. - Київ. - 2008. $392 \mathrm{c.}$

4. Роберт И. В. Средства информационных и коммуникационных технологий в процессах автоматизации информационно-методического обеспечения и 
организационного управления учебным заведением / И. В. Роберт // Ученые записки. - М. : ИИО РАО, 2002. - Вып. 7. - С. 3-17.

5. Романишина О. Я. Формування інформаційної культури студентів коледжів технічного профілю. Дис. ... пед. наук: 13.00 .04 / Тернопільській національний педагогічний університет імені Володимира Гнатюка, - Тернопіль. - 2007. - 177 с.

6. Триус Ю. В. Компютерно-орієнтовані методичні системи навчання математичних дисциплін у вищих навчальних закладах. Дис. ... док. пед. наук: 13.0002 / Національний педагогічний університет імені М. П. Драгоманова. - Київ. - 2005. - 410 с.

7. Закон України «Про Національну програму інформатизації» [Електронний pecypc]. - Режим доступу: http://zakon.rada.gov.ua/laws/show/74/98-вp.

\section{REFERENCES}

1. Adolf V. A. (1997). Et paedagogico Professionally computatrum problems est disciplina professionales [Professional and pedagogical problems of computer training of specialists]. Moscow. (in Russia).

2. Tihonov A. N. (1994). Altius computatrum technology, in educatione [Computer technologies in higher education]. Moscow. (in Russia).

3. Koval T. I. (2008). Quod Teoretichni metodichni Tractatus de profesiynoï pidgotovki informatsiynih tehnologiy maybutnih menedzheriv, ekonomistiv [Theoretical and methodical basis of professional preparation of informational technologies in managerial-economists]. Kyiv. (in Ukrainian).

4. Robert I. V. (2002). Est technologiae rerum nuntiorumque cognitionis ac communicationis processum, in automation ex norma atque subsidium informational et methodo institutione procuratio [Means of information and communication technologies in the processes of automation of information and methodical support and organizational management of educational institutions]. Moscow. (in Russia).

5. Romanishin O. Y. (2007). Formuvannya informatsiynoï culturae studentiv koledzhiv tehnichnogo profilyu [Formulation of the Informational Culture of Students in the College of Technical Profession]. Ternopol. (in Ukrainian).

6. Trius U. V. (2005). Computer-orientovani metodichni sistemi navchannya ically mathematical distsiplin vischih in doctrina impignoratur [Computer-based or methodical systems for navigating mathematical disciplines among wholesalers]. Kyiv. (in Ukrainian).

\section{PEЗЮМЕ}

Олег Митягин кандидат исторических наук, Анатолий Чайковский

доктор исторических наук, профессор Национальный университет обороны Украины имени Ивана Черняховского

\section{Информатизация военного образования - требование общества к подготовке военных специалистов для Вооруженных Сил Украины}

В статье рассматривается актуальность исследования проблемы повышения эффективности военно-педагогического процесса и качества подготовки военных специалистов на основе информатизации военного образования и внедрения информационных технологий. Определено основные задачи, которые должна решать информатизачия образования, обозначено основные общие тенденции и направления внедрения информаџионных технологий в систему военного образования. Рассмотрено актуальность информационной подготовки в системе подготовки военных специалистов. 
Ключевые слова: система военного образования; информационные технологии обучения; компьютерные сети учебных заведений; дистанционное обучение; компьютерная технология обучения; информационная подготовка военных специалистов.

\section{SUMMARY}

SUMMARY Oleh Mitiahin,
Candidate of Historical Science
Anayolyi Chaikovskyi,
Doctor of Historical Science, Professor
National Defence University of Ukraine
named after Ivan Cherniakhovskyi

\section{Informatization of education the requirement of society for military specialists training for the Armed Forces of Ukraine}

Main issue. The Modernization of education is stimulated by social order, and therefore sets new requirements for the level of training of graduates of higher instititutions. But the system of common (integrated) education field in higher military institutions based on the development of education information network for military specialists of the Armed Forces of Ukraine has not yet been created.

Purpose. The purpose of the article is to determine the main tasks for informatization of education and methods of realization; the main general tendencies and course of information technologies implementation into the military education are considered/discussed The relevance of information preparation in the military specialists training system is considered.

Methods of research. Analysis, synthesis, modeling, traditional teaching methods, generalization method.

Results. The argumentation of own corporate information and telecommunication network development for military education system with access to the global Internet, which may solve the issues of operational management and provide the quality of military specialists training of educational level of qualification based on the application of the newest information methods and forms of education. Further research will be devoted.

Originality. In the article the author replied to the question about the informatization of military education and considered the main directions of its development, analyzed the means of information technologies and their influence on the educational process. He substantiated the creation of a computer network of higher military educational institutions.

Conclusion. Dynamic development of computer and communication technologies has identified one of the most significant features of the present - the formation of an information society characterized by global processes of informatization of all spheres of public life, in particular, the educational sphere. One of the prior directions of modernization in this area is the implementation of information and communication technologies, which ensure the restructuring of the educational process in higher military educational institutions and increase its efficiency.

Key words. System of military education; education information technologies; computer network of higher military educational institutions; teaching computer based teaching technologies; distance learning studying; information training preparation of the military specialists. 